\title{
Addictive Behavior in Immigrant Psychiatric Inpatients: the Immigrant Paradox Failure
}

\author{
Vecchi Camilla ${ }^{1}$, Gambaro Eleonora ${ }^{1}$, Di Tullio Elisa ${ }^{1}$, Delicato Claudia ${ }^{1}$, Baralla Francesca ${ }^{3}$, \\ Gramaglia Carla $^{1,2}$, Sarchiapone Marco ${ }^{3,4,5}$, Zeppegno Patrizia ${ }^{1,2}$. \\ ${ }^{1}$ Department of Translational Medicine, Università del Piemonte Orientale, Via Solaroli 17, Novara, Italy \\ ${ }^{2}$ SC Psychiatria, AOU Maggiore della Carità, Corso Mazzini 18, Novara, Italy \\ ${ }^{3}$ Dept. of Medicine and Health Science. University of Molise, Via Francesco de Sanctis, Campobasso Italy \\ ${ }^{4}$ National Institute for Migration and Poverty. Via San Gallicano, 25/A. Rome Italy \\ ${ }^{5}$ Kazakh National Medical University. Tole Bi Street 94, Almaty, Kazakistan \\ Rad je primljen 2.12.2018. Rad je recenziran 10.12.2018. Rad je prihvaćen 21.01. 2019
}

\begin{abstract}
INTRODUCTION: In the last years migration has become a major political and social concern in West-Europe. Some researchesindicate that immigrants are more prone to certain psychiatric disorders, while other show the "immigrant paradox".Data about immigrants' admission to acute psychiatry settings and substances and alcohol use-related considerations are still controversial.

AIMS: To evaluate data about immigrants' admission to the acute Italian Psychiatry Ward of Hospital of Novara, focusing on substances and alcohol.

METHODS: The study was performed from January to December 2017, without any exclusion criteria. The final database contains detailed information including diagnostic treatment-related and sociodemographic characteristics. The sample was divided into two subgroups: immigrants with (SAU) or without a history of substances or alcohol abuse (N-SAA). Each patient was assessed with the Health of the Nation Outcome Scales and the Clinical Global Impression.

RESULTS: Of the total of 71 immigrants (mean age 37.95 years), 34 were female.49.3\% of them with SAU. Specifically, immigrants with SAU seemed to have a shorter hospital stayand to obtain higher scores on the subscale "behavior" and "social" of HONOS $(\mathrm{p}<0.05)$. Differences in the use of antidepressants and atypical antipsychotics were showed.

Conclusion: From our study resulted that immigrants are more prone to develop addictive behavior, maybe due to stress related to the migration, without information on the causality of relationship.This issue needs to be expanded in order to possibly align psychiatric services to the needs of immigrant patients.
\end{abstract}

Keywords: Immigrants, Substance Use Disorders, Psychiatric Ward

Corresponding author:

Dr. Eleonora Gambaro

Università del Piemonte Orientale, via Solaroli 17, Novara

Email: eleonora.gambaro22@gmail.com,

Fax: 0321-3733212 


\section{INTRODUCTION}

In the last few years migration has become a major political and social concern in West European societies (1). People migrate from rural to urban areas or across borders for many reasons including economic educational or political (2).

Migration to Italy is relatively recent mainly developed in the last 20 years (3). In the last decades there has been a steady increase in immigrants in Italy. From 2006 to 2016 immigrant population has nearly doubled: in 2006 immigrants in Italy were 2.670 .514 (4.5\% of the Italian population) while at the $1^{\text {st }}$ January 2016 they were 5.026 .153 (83\% of the Italian population). As for the total Italian population Piedmont region experienced an almost $50 \%$ increase of its immigrant population between 2006 (231.611: 533\% of the resident population) and 2016 (422.027: 958\% of the resident population). A similar trend was observed in Novara province over the same period (from $19.574-5.51 \%$ of the total population- in 2006 to $37.385-10.09 \%$ - in 2016) (4). As migration has become an outstanding phenomenon, mental health problems in immigrants have to be considered because of their impact in many areas from health to economic policies (5).

There are increasing research evidences indicating that immigrants are more prone to certain psychiatric disorders $(2,6)$. For example the association between immigration and increased risk for psychosis is well established (2,3). Moreover the process of migration can lead to many other mental health disorders e.g. PTSD, common mental disorders, eating disorders, suicidal acts etc. (2).

On the contrary a growing body of literature shows the "immigrant paradox" $(7,8)$. According to this construct immigrants tend to show better outcomes then natives (e.g. academic achievement psychological wellbeing and healthier behaviours) in spite of all the adversities linked to the migration process they have to face. Research on this field has often shown that alcohol and substance use were less common in immigrants then natives.

One explication of this phenomenon could be the selection of healthier individuals during the migration process; furthermore, sociocultural norms of some countries could have a protective role against the use of alcohol and substances $(7,9)$. Assessing cultural aspect linked to the country of origin would be important in order to identify high risk subgroups and personalize medical treatments (10).

On the other hand, previous research on the "immigrant paradox" have shown that this phenomenon varies considerably depending on the host country. In several European countries, immigrants exhibit poorer health than the native population probably due to a less ingrained of immigration in the national identity (9).

Another key issue in the migration field is the access to mental health services. Many Authors suggest that immigrant's pathways to specialist services are more complex and inequity in treatment may lead to increased disease severity, longer duration of untreated illness and consequent emergency referrals. In emergency psychiatry immigrants in Europe appear at higher risk of compulsory admissions and other coercive measures $(1,11,12)$. Furthermore, immigrants may also have special needs such as lack of linguistic abilities which must be taken into account using a number of strategies at individual local and national policy levels (2).

Recent Italian studies suggest that immigrants use community mental health services less than native population; however, immigrants tend to be more frequently admitted to general hospital psychiatric units during acute phases, and both the utilization rates and gender differ greatly depending on the country of origin $(13,14)$. The underutilization of mental health services is due to many and complex factors and awareness of these should lead to the development of strategies to face the problems and improve both accessibility and patient-care quality for immigrants (13). Unfortunately, data about immigrant psychiatric inpatients are still scarce.

Social support seems to play a key role in immigrant's mental health. As defined by Cohen social support refers to a social network's provision of psychological and material resources intended to benefit an individual's ability to cope with stress (15). Some studies on this field highlighted that higher 
levels of social support could mitigate the effect of stress on maladaptive outcomes such as substance use. Enhancing social support could be an effective measure to lower for instance alcohol or substance use among immigrants (16). Under current Italian legislation migrants legally residing in Italy or regularly working have the same rights and duties as Italian citizens and the same treatment options (17). Irregular migrants have access to urgent or essential healthcare in outpatient and inpatient facilities and may also take advantage of preventive health programs. Irregular migrants are not reported to the immigration authorities if they seek medical assistance; clinicians only obligation relates to the notification of crimes and applies to all patients regardless of origin. Mental health services in Italy are delivered primarily as outpatient services; the psychiatric wards of general hospitals usually admitted patients in the acute phase for a short period (18).

In conclusion literature data on this topic show two main gap in knowledge; on one hand data about immigrant admitted to acute psychiatry settings are scarce, on the other hand the "immigrant paradox" concerning substances and alcohol use among immigrants is still controversial.

The aim of this study is to evaluate data from immigrants admitted to an acute Italian psychiatry ward focusing on substances and alcohol use in order to possibly draw conclusions on a psychiatric treatment and service level. According to the "immigrant paradox" we hypothesize to find a little proportion of immigrants using alcohol or substances moreover we expected to find little social support in such patients.

\section{MATHERIALS AND METHODS}

The study was performed between the $1^{\text {st }}$ January and the $31^{\text {st }}$ December 2017 at the Psychiatry Ward of "Maggiore dellaCarità Hospital" (MCH). The $\mathrm{MCH}$ is the second largest general hospital in Piedmont the main reference hospital for all North-Eastern Piedmont and its catchment area is representative of the whole region (19). Psychiatry ward admits patients during the acute phases of their conditions generally after a consultation at the Emergency Department in order to exclude organic conditions. All adult immigrants admitted to the Psychiatry ward of $\mathrm{MCH}$ were enrolled during the study period. We considered as immigrant both foreigners and naturalized people: the first are individuals without Italian nationality while the second are those born abroad who acquired Italian citizenship (20). No exclusion criteria were applied. Medical history, demographic information, clinical data, and treatment characteristics were collected for each patient. Diagnosis were made according to ICD 10 criteria. The final database contains thus detailed information including diagnostic treatment-related and sociodemographic characteristics. Based on all data recorded our sample was then divided into two subgroups: immigrants with or without a history of substances or alcohol abuse. Patients' names were registered to check for possible multiple admission and then replaced by a numerical code which was recorded in a separate datasheet whose access is restricted to the researchers involved. Each patient was assessed with the Health of the Nation Outcome Scales (HoNOS) and the Clinical Global Impression (CGI). The HoNOS is a simple rating scale for clinicians that covers clinical problems and social functioning with reasonable adequacy. It consists of 12 items each ranging from 0 (no problem) to 4 (severe problem). The 12 items are scored into four subscales: Behaviour (items 1-3), Impairment (items 4-5), Symptoms (items 6-8) and Social (items 9-12). See Table 1 for a more detailed explication of this measure (21). The sum of the 12 items provides a total score (range of 0-48). HoNOS can be interpreted at the item subscale or total score level $(22,23)$. The Clinical Global Impression scale (CGI) is a classic instrument for making global assessments. This scale yields three different measures: Severity of illness (assessment of patient's current symptom severity), Global improvement (comparison of patient's baseline condition with his/her current condition), Efficacy index (comparison of patient's baseline condition with a ratio of current therapeutic benefit to severity of side effects). The CGI has been widely used in clinical research and especially in clinical trials concerning psychotropic treatments $(24,25)$. 
Table 1. (adapted from 21)Items structure and scoring for the HoNOS

\begin{tabular}{|c|c|c|c|}
\hline Instrument & Item & $\begin{array}{c}\text { Subscales/ } \\
\text { sections }\end{array}$ & Scoring \\
\hline HoNOS & $\begin{array}{l}\text { 1. Overactive aggressive disruptive or agitated } \\
\text { behaviour } \\
\text { 2. Non-accidental self-injury } \\
\text { 3. Problem drinking or drug taking } \\
\text { 4. Cognitive problems } \\
\text { 5. Physical illness or disability problems } \\
\text { 6. Problems associated with hallucinations } \\
\text { and delusions } \\
\text { 7. Problems with depressed mood } \\
\text { 8. Other mental and behavioural problems } \\
\text { 9. Problems with relationships } \\
\text { 10. Problems with activities of daily living } \\
\text { 11. Problems with living conditions } \\
\text { 12. Problems with occupation and activities }\end{array}$ & $\begin{array}{l}\text { Behaviour } \\
(1-3) \\
\text { Impairment } \\
(4-5) \\
\text { Symptoms } \\
(6-8) \\
\text { Social (9-12) }\end{array}$ & $\begin{array}{l}\text { Each item rated on a 5-point scale: } \\
\text { 0. no problem } \\
\text { 1. minor problem requiring no action } \\
\text { 2. mild problem but definitely present } \\
\text { 3. moderately severe problem } \\
\text { 4. severe to very severe problem. } \\
\text { Scoring yields individual item scores } \\
\text { subscale scores and a total score. }\end{array}$ \\
\hline
\end{tabular}

In accordance with Italian legislation no local ethics board permission was necessary as the study was observational in nature and only routine assessment was used. Nevertheless the department head reviewed the study for ethical standards.

We calculated descriptive statistics: frequencies and percentages in the case of qualitative variables and means, standard deviations (SDs) and maxima and minima in the case of quantitative variables. Group differences in categorical variables were evaluated using the chi-squared test and group differences in continuous variables were assessed using a $\mathrm{t}$-test. The statistical significance level was set at $\mathrm{p}<$ .05. Statistical analyses were performed with STATA $11(26)$.

\section{RESULTS}

A total of 71 immigrants were admitted to the Psychiatry Department of the $\mathrm{MCH}$ during the study period. The mean age was 37.95 years (SD 12.59; min 17 - $\max 69) ; 37$ (52.12\%) patients were male and 34 were female (47.88\%). Almost one half of patients enrolled in the study used alcohol or drug $(n=35$; 49.3\%); in particular 6 of them used only alcohol 19 were cannabis abusers while 10 patients were multiple substance abuser (more than one drug or drug and alcohol).

In Table 2 are listed the main sociodemographic features of the two subgroups. 
Vecchi C, Gambaro E, Di Tullio, Delicato C, Baralla F, Gramaglia C, Sarchiapone M, Zeppegno P. Addictive behavior in immigrant psychiatric inpatients: the immigrant paradox failure. Zdravstveni glasnik. 2019; 5(1): str 13-23.

Table 2.Sociodemographic features of the two subgroups

\begin{tabular}{|c|c|c|c|c|}
\hline & & $\begin{array}{c}\text { ALCOHOL/ } \\
\text { SUBSTANCES } \\
\mathbf{N}(\%) \\
\end{array}$ & $\begin{array}{c}\text { NO ALCOHOL/SUBSTANCES } \\
\text { N (\%) }\end{array}$ & p value \\
\hline Patients & & $35(49 \%)$ & $36(51 \%)$ & \\
\hline \multirow[t]{2}{*}{ Sex } & $\mathrm{M}$ & $27(72.97 \%)$ & $10(27.03 \%)$ & \multirow[t]{2}{*}{$<0.000$} \\
\hline & $\mathrm{F}$ & $8(23.53 \%)$ & $26(76.47 \%)$ & \\
\hline Age & & 33.7 & 42.22 & 0.003 \\
\hline \multirow[t]{4}{*}{ Marital Status } & unmarried & $21(67.7 \%)$ & $10(32.3 \%)$ & \multirow[t]{4}{*}{0.03} \\
\hline & married & $12(41.37 \%)$ & $17(48.63 \%)$ & \\
\hline & divorced & $2(25 \%)$ & $6(75 \%)$ & \\
\hline & widow & $0(0 \%)$ & $2(100 \%)$ & \\
\hline \multirow[t]{4}{*}{ Education } & Elementary school & $2(25 \%)$ & $6(75 \%)$ & \multirow[t]{4}{*}{0.013} \\
\hline & Middle school & $19(61.29 \%)$ & $12(38.71 \%)$ & \\
\hline & High school & $5(29.41 \%)$ & $12(70.59 \%)$ & \\
\hline & Degree & $2(28.58 \%)$ & $5(71.42 \%)$ & \\
\hline \multirow[t]{3}{*}{ Religion } & Christian & $15(41.67 \%)$ & $21(58.3 \%)$ & \multirow[t]{3}{*}{0.01} \\
\hline & Muslim & $10(50 \%)$ & $10(50 \%)$ & \\
\hline & Other & $2(28.57 \%)$ & $5(71.43 \%)$ & \\
\hline
\end{tabular}

We found statistically significant differences $(\mathrm{p}<0.05)$ in the use of alcohol or substances comparing patients' area of origin (see table 3 for more details).

Table 3. Disparity in alcohol or substances consumption in different area of origin.

\begin{tabular}{|l|l|l|}
\hline & \multicolumn{1}{|c|}{$\begin{array}{c}\text { ALCOHOL/ } \\
\text { SUBSTANCES } \\
\text { N (\%) }\end{array}$} & \multicolumn{1}{|c|}{$\begin{array}{c}\text { NO ALCOHOL/SUBSTANCES } \\
\text { N (\%) }\end{array}$} \\
\hline European Community (EC) & $11(39.28)$ & $17(60.72)$ \\
\hline Europe (not EC members) & $2(40)$ & $3(60)$ \\
\hline North Africa & $7(77.78)$ & $2(22.22)$ \\
\hline Central-South Africa & $7(63.63)$ & $4(36.37)$ \\
\hline Middle East & $3(37.5)$ & $5(62.5)$ \\
\hline Central-South America & $5(50)$ & $5(50)$ \\
\hline
\end{tabular}

Patients using alcohol or substances spent significantly shorter time in the hospital (6.342 days; $\mathrm{p}=0.00046)$ compared to the non-abuser group (12.527 days). No differences were found concerning mandatory medical treatments in fact we recorded 13 mandatory medical treatment in the abuser group and 22 in the non-abuser group this difference was not statistically significant ( $p=0.097$ ).

In the abuser group the most frequent diagnosis were: firstly "neurotic stress-related and somatoform disorders or disorders of adult personality and behavior" and secondly "mental and behavioral disorders due to psychoactive substance use". Even in the non-abuser group most of patients were diagnosed by "neurotic stress-related and somatoform disorders or disorders of adult personality and behavior" while the second most frequent diagnosis was "schizophrenia schizotypal and delusional disorders" (See table 4 for more details). 
Vecchi C, Gambaro E, Di Tullio, Delicato C, Baralla F, Gramaglia C, Sarchiapone M, Zeppegno P. Addictive behavior in immigrant psychiatric inpatients: the immigrant paradox failure. Zdravstveni glasnik. 2019; 5(1): str 13-23.

Table 4.Diagnosis in the two subgroups

\begin{tabular}{|l|l|l|}
\hline & \multicolumn{1}{|c|}{$\begin{array}{c}\text { ALCOHOL/ } \\
\text { SUBSTANCES } \\
\text { N (\%) }\end{array}$} & $\begin{array}{l}\text { NO ALCOHOL/SUBSTANCES } \\
\text { N (\%) }\end{array}$ \\
\hline Organic including symptomatic mental disorders & $2(100)$ & $0(0)$ \\
\hline $\begin{array}{l}\text { Mental and behavioural disorders due to psychoactive sub- } \\
\text { stance use }\end{array}$ & $14(100)$ & $0(0)$ \\
\hline Schizophrenia schizotypal and delusional disorders & $1(7.14)$ & $13(92.86)$ \\
\hline Mood [affective] disorders & $3(30)$ & $7(70)$ \\
\hline $\begin{array}{l}\text { Neurotic stress-related and somatoform disorders OR Dis- } \\
\text { orders of adult personality and behavior }\end{array}$ & $15(48.39)$ & $16(51.61)$ \\
\hline
\end{tabular}

Analyzing medical treatments, we found significative differences in the use of antidepressants and atypical antipsychotics in the two subgroups (respectively: $\mathrm{p}=0.001 ; \mathrm{p}=0.007$ ): both of them were used more frequently in the non-abuser group than in patients using alcohol or substances. Table 5 provides more details on this topic. Patients in the abuser group were more likely to obtain higher scores on the subscale "behavior" and "social" of HoNOS both at admission and at discharge (see Table 6). Conversely we failed to find any statistically significant differences concerning CGI results in the two subgroups both at admission and at discharge.

Table 5.Therapies in the two sub groups.

\begin{tabular}{|l|l|l|l|}
\hline & \multicolumn{1}{|c|}{$\begin{array}{c}\text { ALCOHOL/ } \\
\text { SUBSTANCES N }\end{array}$} & $\begin{array}{c}\text { NO ALCOHOL/ } \\
\text { SUBSTANCES N }\end{array}$ & p value \\
\hline Antidepressants & 5 & 18 & 0.001 \\
\hline Benzodiazepines & 29 & 28 & 0.59 \\
\hline Mood stabilizers & 7 & 5 & 0.49 \\
\hline Typical antipsychotics & 12 & 10 & 0.39 \\
\hline Atypical antipsychotics & 4 & 14 & 0.007 \\
\hline Long acting injectable antipaychotics & 10 & 9 & 0.73 \\
\hline
\end{tabular}

Table 6.HoNOS scores at the admission and at the discharge in the two subgroups

\begin{tabular}{|c|c|c|c|c|}
\hline & & $\begin{array}{c}\text { ALCOHOL/ } \\
\text { SUBSTANCES N } \\
\text { (SD) } \\
\end{array}$ & $\begin{array}{c}\text { NO ALCOHOL/ } \\
\text { SUBSTANCES N } \\
\text { (SD) }\end{array}$ & p value \\
\hline \multirow[t]{5}{*}{ HoNOS IN } & Behaviour & 5.17 (SD 1.99) & 2 (SD 1.89) & $<0.000$ \\
\hline & Impairment & $4.57(1.39)$ & 2.66 (SD 3.07) & 0.1 \\
\hline & Symptoms & 5.28 (SD 2.54) & $4.68(\mathrm{SD} 2.41)$ & 0.051 \\
\hline & Social & 6.37 (SD 3.40) & $4.78(\mathrm{SD} 3.66)$ & 0.062 \\
\hline & Total & 17.65 (SD 5.54) & $12.89($ SD 5.17) & 0.0003 \\
\hline \multirow[t]{5}{*}{ HoNOS OUT } & Behaviour & 2.83 (SD1.8) & 0.41 (SD 0.94) & 0.000 \\
\hline & Impairment & 0.88 (SD 1.3) & 0.53 (SD 1.29) & 0.2 \\
\hline & Symptoms & 1.91 (SD 1.63) & 2.5 (SD 2.12) & 0.197 \\
\hline & Social & $6(\mathrm{SD} 3.49)$ & 4.1 (SD 3.38) & 0.023 \\
\hline & Total & 11.73 (SD 5.56) & 7.28 (SD 4.41) & 0.0004 \\
\hline
\end{tabular}




\section{DISCUSSION}

The present study tries to shed light in our understanding of the link between immigration and use of alcohol and substances in a population of immigrant psychiatric inpatients. Interestingly contrary to our first hypothesis we found a quite big proportion of immigrant patients using alcohol or substances and this seems to be in contrast with previous findings of the "immigrant paradox" $(7,9)$. In agreement with our results one previous study about general population in France failed to find any "immigrant paradox" regarding alcohol abuse in immigrant population (9). As already pointed out by Rolland B. et al the "immigrant paradox" seems to vary considerably in different countries and it seems to be more pronounced in countries with a long history of immigration and in which immigrants are more integrated in the society. Unfortunately while there are many evidences about US countries there is a dearth of data about the "immigrant paradox" in European countries. In particular there aren't studies about Italian general population on this topic. It is thus difficult to compare our data to the US ones because of the great differences of the social fabric of the two countries.

Anyway, analyzing the results of our study, one thing has to be considered: we focused on a population of psychiatric inpatients, for this reason probably our results could be different of what we expected to find in the general population, and results could not be extended to general population as well.

Consistent with previous results, patients in the abuser group were younger, unmarried and predominantly male. As highlighted in the NESARC study the causal direction between unmarried status and psychiatric disorder is unclear. On one hand psychiatric disorders such as alcohol or substances abuse can impair the ability to establish or maintain a marriage; on the other hand the lack of marital support may also increase the risk for disorders (27).

In our sample it seems that religion, especially Christian religion, could be a protective factor against the use of alcohol or substances even if sample size is still too small to allow specific conclusions on this matter. Our findings are in line with previous studies showing that in some religious doctrines the prohibition of the use of alcohol or drugs result in lower rates of substance abuse and dependence among individuals that subscribe to such beliefs (28). As observed in the article by Edlund et al., it could be an overlap between religion and social support because many times religious organizations provide even social support (28).

Concerning social support, we found that patients in the abuser group scored higher on the HoNOS "social" subscale. In other words it seems that in our sample immigrants experiencing lower level of social support are more prone to develop addictive behavior and at discharge it seems more difficult to engage them in social support networks. Some previous studies among Hispanic immigrants in the USA suggest that social support may be a protective factor against alcohol use; however no prior studies have investigated the effect of social support on immigration stress reducing in that way alcohol use behaviors (15).

Literature data reveal different proportion of addictive behaviors depending on the area of origin (10). This seems to be confirmed in our study; unfortunately due the small sample size it is not possible now to outline accurate conclusion in this domain.

Length of hospitalization show a statistically significant difference between the two subgroups; this is not surprising due to the Italian structure of addiction services. Patients using alcohol or substances in Italy are treated in specific centers for addiction and this seems to be the main reason why they need to stay shorter in the hospital compared to the non-abuser group.

This study shows no differences between the two subgroups concerning Compulsory commitment to care (CCC). CCC for adult with substance use disorders (i.e. dependence or abuse or harmful use of alcohol and/or drugs) or misuse problems (problematic substance use i.e. use related to medical emotional social or legal problems whether these meet diagnostic criteria of substance use disorders or not) is a fairly common legislative option worldwide (29). Particularly in Italy CCC is very well 
defined by legislation and it could be done only if the clinician identifies the presence of specific acute psychiatric symptoms at the moment of evaluation (30). The intoxication of alcohol or drugs may be associated with the presentation of acute psychiatric symptoms that should be solved when the purity of the substances is demonstrated. Therefore in such an event it is preferable to adopt the admission to hospital in "stato di necessità" (art. 54 CodicePenale) (31). This rule justifies the physical or pharmacological restraint without patient's consent. This would also explain that CCC is not more frequent among patients with acute substances or alcohol intoxication. Finally as we expected we found differences in the prescription of pharmacological treatment between the two groups with a more frequent antidepressants and atypical antipsychotics prescription in the non-abuser group. This could be explained by the fact that addiction is a chronic disorder that requires a long-term approach in which pharmacotherapies now play an important role in the treatment of SUDs at the levels of detoxification, initial recovery and relapse prevention (32).

\section{CONCLUSION}

Interestingly in conclusion it seems that in our sample immigrants are more prone to develop addictive behavior maybe due to stress related to the migration process. This issue needs to be expanded and further studied in order to possibly align psychiatric services to the needs of this specific population.

This is one of the first studies assessing the topic of addictive behavior in a specific population of immigrant psychiatric inpatients; moreover, we use validated test to assess clinical and sociodemographic characteristic in order to allow better comparison with literature data. However, at the moment due to the small sample size it is not possible to stratify the sample in order to see differences in the area of origin or in the use of different substances. Furthermore, due to the cross-sectional design of this study it is not possible to assess causality of relationship.

Results of our studies are really thought provoking: assessing the needs of addictive immigrant patients seems to be the challenge of the next years. This is the reason why we are continuing data collection in order to achieve a bigger sample and compare this data to the ones of native psychiatric inpatients with the aim of improving the design and implementation of clinical intervention in this population. 


\section{BIBLIOGRAPHY}

1. Lay B, Lauber C, Nordt C, Rössler W. Patterns of inpatient care for immigrants in Switzerland: a case control study. Soc Psychiatry Psychiatr Epidemiol. 2006;41(3):199-207.

2. Bhugra D, Gupta S, Schouler-Ocak M, Graeff-Calliess I, Deakin NA, Qureshi A, et. al. EPA guidance mental health care of migrants.; European Psychiatric Association. Eur Psychiatry. 2014;29(2):107-15.

3. Tarricone I et al. First-episode psychosis and migration in Italy (PEP-Ita migration): a study in the Italian mental health services BMC Psychiatry 2014;14:186.

4. Retrieved from: http://www.tuttitalia.it/statistiche/cittadini-stranieri-2016/

5. Lindert J, Schouler-Ocak M, Heinz A, Priebe S. Mental health health care utilisation of migrants in Europe. Eur Psychiatry. 2008;23(1):14-20

6. Müller MJ, Zink S, Koch E. The Negative Impact of an Uncertain Residence Status: Analysis of Migration-Related Stressors in Outpatients with Turkish Migration Background and Psychiatric Disorders in Germany Over a 10-Year Period (2005-2014). J Immigr Minor Health. 2018;20:317-326.

7. Di Cosmo C, Milfont TL, Robinson E, Denny SJ, Ward C, Crengle S, Ameratunga SN. Immigrant status and acculturation influence substance use among New Zealand youth. Aust N Z J Public Health. 2011;35(5):434-41.

8. Sam DL. Acculturation and health in Cambridge Handbook of Acculturation Psychology (Sam DL Berry JW eds) Cambridge: University Press Cambridge. 2006.

9. Rolland B, Geoffroy PA, Pignon B, Benradia I, Font H, Roelandt JL, et al. Alcohol Use Disorders and Immigration up to the Third Generation in France: Findings from a 39617-Subject Survey in the General Population.Alcohol Clin Exp Res. 2017;41(6):1137-1143.

10. Sordo L, Indave BI, Vallejo F, Belza MJ, Sanz-Barbero B, Rosales-Statkus M, et al. Effect of country-of-origin contextual factors and length of stay on immigrants' substance use in Spain.Eur J Public Health. 2015;25(6):930-6.

11. Tarsitani L Pasquini M Maraone A Zerella MP Berardelli I Giordani R Polselli GM Biondi M. Acute psychiatric treatment and the use of physical restraint in first-generation immigrants in Italy: a prospective concurrent study. Int J Soc Psychiatry. 2013;59(6):613-8

12. Tarricone I, Stivanello E, Ferrari S, Colombini N, Bolla E Braca M, et al. Migrant pathways to community mental health centres in Italy. Int J Soc Psychiatry. 2012;58(5):505-11.

13. Spinogatti F, Civenti G, Conti V, Lora A. Ethnic differences in the utilization of mental health services in Lombardy (Italy): an epidemiological analysis. Soc Psychiatry Psychiatr Epidemiol. 2015;50(1):59-65.

14. Gramaglia C, Gambaro E, Rossi A, Toso A, Feggi A, Cattaneo CI, et al. Immigrants' Pathways to Outpatient Mental Health: Are there Differences with the Native Population? J Immigr Minor Health. 2016;18(4):878-85.

15. Cohen S. Social relationships and health. American Psychologist. 2004; 59:676-684.

16. Cano MÁ Sánchez M Trepka MJ Dillon FR Sheehan DM Rojas P et al. Immigration Stress and Alcohol Use Severity Among Recently Immigrated Hispanic Adults: Examining Moderating Effects of Gender Immigration Status and Social Support. J Clin Psychol. 2017;73(3):294307.

17. Decreto Legislativo 25 luglio 1998, n. 286. Gazzetta Ufficiale n. 191, 18th August 1998 Supplemento Ordinario n. 139.

18. Gramaglia C, Gambaro E, Delicato C, Di Marco S, Di Tullio E, Vecchi C et al. Pathways to and Results of Psychiatric Consultation for Patients Referred from the Emergency Department. Are there Differences between Migrant and Native Patients? Transcult Psychiatry. 2018;10:1363461518798844.

19. Zeppegno P, Gramaglia C, Castello LM, Bert F, Gualano MR, Ressico F, et al. Suicide attempts and emergency room psychiatric consultation. BioMed Central. 2015;15:13. 
20. National Institute of Statistics. Immigrati e nuovi cittadini. Tassi demografici delle Province del Piemonte. 2015. Retrieved from http://www. demos.piemonte.it/index.php? Option=com_ content \&view=article \&id=74\&Item id11=Piemonte (2014).

21. Pirkis JE, Burgess PM, Kirk PK, Dodson S, Coombs TJ, Williamson MK. A review of the psychometric properties of the Health of the $\mathrm{Na}$ tion Outcome Scales (HoNOS) family of measures. Health Qual Life Outcomes. 2005;28;3:76.

22. Luo W, Harvey R, Tran T, Phung D, Venkatesh S, Connor JP. Consistency of the Health of the Nation Outcome Scales (HoNOS) at inpatient-to-community transition. BMJ Open. 2016;27;6(4).

23. Wing JK Beevor AS Curtis RH Park SB Hadden $S$ Burns A. Health of the Nation Outcome Scales (HoNOS). Research and development. Br J Psychiatry. 1998;172:11-8.

24. Kadouri A, Corruble E, Falissard B. The improved Clinical Global Impression Scale (iCGI): development and validation in depression. BMC Psychiatry. 2007;6;7:7.

25. Guy W. Clinical Global Impression. ECDEU Assessment Manual for Psychopharmacology revised National Institute of Mental Health Rockville MD. 1976
26. StataCorp. Stata Statistical Software: Release 12. College Station, TX: StataCorp LP. 2011.

27. Hasin DS, Grant BF. The National Epidemiologic Survey on Alcohol and Related Conditions (NESARC) Waves 1 and 2: review and summary of findings. Soc Psychiatry Psychiatr Epidemiol. 2015;50(11):1609-40.

28. Edlund MJ, Harris KM, Koenig HG, Han X, Sullivan G, Mattox R, Tang L. Religiosity and decreased risk of substance use disorders: is the effect mediated by social support or mental health status? Soc Psychiatry Psychiatr Epidemiol. 2010;45(8):827-36.

29. Israelsson $M$, Nordlöf $K$, Gerdner A. European laws on compulsory commitment to care of persons suffering from substance use disorders or misuse problems- a comparative review from a human and civil rights perspective. Substance Abuse Treatment Prevention and Policy. 2015;10:34.

30. Legge 13 maggio 1978 n. 180 " Accertamenti e trattamenti sanitari volontari e obbligatori"

31. Retrieved from: http://www.jpsychopathol. it/article/gli-interventi-non-volontari-la-gestione-medica-e-le-implicazioni-legali/

32. Douaihy AB, Kelly TM, Sullivan C. Medications for Substance Use Disorders. Social Work in Public Health. 2013;28(0);264-278. 


\title{
Ovisnost psihijatrijskih pacijenata medu imigrantimar neuspjeh imigrantskog paradoksa
}

\author{
Vecchi Camilla ${ }^{1}$, Gambaro Eleonora ${ }^{1, *}$, Di Tullio Elisa ${ }^{1}$, Delicato Claudia ${ }^{1}$, Baralla Francesca ${ }^{3}$, \\ Gramaglia Carla $^{1,2}$, Sarchiapone Marco ${ }^{3,4,5}$, Zeppegno Patrizia ${ }^{1,2}$. \\ ${ }^{1}$ Odsjek za translacijsku medicinu, Sveučilište Istočnog Pijemonta, Via Solaroli 17, Novara, Italija \\ ${ }^{2}$ SC Psychiatria, AOU Maggiore della Carità, Corso Mazzini 18, Novara, Italija \\ ${ }^{3}$ Odsjek za medicinu i zdravstvo,Sveučilište u Moliseu, Via Francesco de Sanctis, Campobasso, Italija \\ ${ }^{4}$ Nacionali institut za migracije i siromaštvo,Via San Gallicano, 25/A. Rim, Italija \\ ${ }^{5}$ Nacionalno medicinsko sveučilište u Kazahstanu. Tole Bi Street 94, Almati, Kazahstan.
}

\author{
* Kontakt za razmjenu informacija: \\ Dr. Eleonora Gambaro \\ Sveučilište Istočnog Pijemonta, via Solaroli 17, Novara \\ Email: eleonora.gambaro22@gmail.com,
}

Fax: 0321-3733212

\section{SAŽETAK}

UVOD: Posljednjih godina migracije su postale glavni politički i društveni problem u Zapadnoj Europi. Neka istraživanja ukazuju na činjenicu da su imigranti skloniji određenim psihijatarskim poremećajima dok druga ukazuju na „imigrantski paradoks“. Podaci o prihvatu imigranta u akutna psihijatrijska okuženja, pijenje alkoholnih pića i zlouporaba psihoaktivnihtvari još uvijek su kontraverza.

CILJ ISTRAŽIVANJA: Analiza podataka o prijemu imigranta na psihijatrijsko odjeljenje bolnice u Novari a fokus je na zlouporabi psihoaktivnih tvarii pijenju alkoholnih pića.

METODE: Istraživanje je provedeno u razdoblju od siječnje do prosinca 2017. godine, bez kriterija za isključivanje. Završna baza podataka sadrži detaljne informacije koje uključuju dijagnostičke tretmane i socio-demografska obilježja. Uzorak je podijeljen u dvije skupine: imigranti sa (SUA) iimigranti bez povijesti pijenja alkoholnih pića i zlouporabe psihoaktivnih tvari(N-SAA). Svaki pacijent je procijenjen pomoću ljestvice za procjenu nacionalnog zdravlja (HoNos skala) i ljestvice općeg kliničkog utiska.

REZULTATI: Od ukupnog broja imigranata (71) prosječne dobi 37,95 godina, 34 su bile žene. Naime, imigranti sa poviješću pijenja alkoholnih pića i zlouporabe psihoaktivnih tvariimaju kraći boravak u bolnici i više ocjene na HoNos skalama za „ponašanje“ i „društvo“ ( $\mathrm{p}<0.05)$. Uočene su razlike u uporabi antidepresiva i atipičnih antipsihotika.

ZAKLJUČAK: Rezultati našeg istraživanja pokazuju da su imigranti skloniji razvijanju ovisničkog ponašanja, možda zbog stresa uzrokovanog migracijom, ali bez informacija o uzročnoj povezanosti.

Ključne riječi: imigranti, poremećaji uporabe psihoaktivnih tvari, psihijatrijski odjel 